RAD Conference Proceedings, vol. 3, pp. 52-57, 2018

ISSN 2466-4626 (online) | DOI: 10.21175/RadProc.2018.11

www.rad-proceedings.org

\title{
DETERMINING THE ZONE OF INFLUENCE OF TRANSMISSION OVERHEAD POWER LINES FROM THE ASPECT OF NON-IONIZING RADIATION
}

\author{
Maja Grbić*, Aleksandar Pavlović \\ University of Belgrade, Nikola Tesla Electrical Engineering Institute, Belgrade, Serbia
}

\begin{abstract}
The paper presents the methodology for determining the area in the vicinity of overhead power lines where the levels of non-ionizing radiation are significant in the context of current regulations referring to the protection of the general public in the Republic of Serbia. A brief review of Serbian legislation on protection of the general public from power frequency electromagnetic fields is given. The zones of influence of $110 \mathrm{kV}, 220 \mathrm{kV}$ and $400 \mathrm{kV}$ transmission overhead power lines are determined by calculations. The configurations of power lines which result in the widest zone of influence are analyzed for each voltage level. The influence of phase conductor heights on the width of the zone is also considered. Determining the width of the zone of influence is very important for planning the construction of new power lines near residential areas, as well as for the construction of residential buildings near existing lines. It is also significant when it is necessary to determine the locations in the vicinity of overhead power lines where more detailed testing of non-ionizing radiation should be performed by measurements.
\end{abstract}

Key words: Electric field strength, overhead power line, magnetic flux density, non-ionizing radiation, zone of influence

\section{INTRODUCTION}

Determining the zone of influence of transmission overhead power lines from the aspect of non-ionizing radiation is highly significant for planning the construction of new power lines near residential areas, as well as for the construction of residential buildings near existing power lines. It is also very important when it is necessary to determine the locations in the vicinity of overhead power lines where more detailed non-ionizing radiation testing should be performed by measurements.

The aim of this paper is to determine the maximum width of the zone of influence of $110 \mathrm{kV}, 220 \mathrm{kV}$ and $400 \mathrm{kV}$ transmission overhead power lines, taking into consideration typical phase conductor heights and the most common configurations of single- and doublecircuit power lines pertaining to the aforementioned voltage levels. The zones of influence are determined by electric field strength and magnetic flux density calculations.

In this paper, the term zone of influence refers to the area in the vicinity of overhead power lines where the levels of electric field strength and magnetic flux density are significant in the context of current regulations referring to the protection of the general public from non-ionizing radiation in the Republic of Serbia.

\section{SERBIAN AND INTERNATIONAL LEGISLATION ON PROTECTION FROM NON-IONIZING RADIATION}

The Recommendation 1999/519/EC [1] establishes a framework for harmonized protection of the general public from non-ionizing radiation, to which all European Union countries should comply in adopting local regulations. Reference levels established in [1] for power frequency $(50 \mathrm{~Hz})$ field amount to $5 \mathrm{kV} / \mathrm{m}$ for electric field strength and $100 \mu \mathrm{T}$ for magnetic flux density. On the other hand, reference levels established in ICNIRP Guidelines [2] amount to $5 \mathrm{kV} / \mathrm{m}$ and $200 \mu \mathrm{T}$.

The Republic of Serbia fulfilled the requirements of [1] in 2009 by adopting the Law on Protection from Non-Ionizing Radiation [3] and six regulations.

The subject of the Regulation on Limits of Exposure to Non-Ionizing Radiation [4] are so-called "areas of increased sensitivity", which include "residential areas where people can stay 24 hours a day, schools, homes, preschools, maternity wards, hospitals, tourist facilities, children playgrounds, and areas of undeveloped parcels of land intended, according to the urban development plan, for specified purposes, in accordance with recommendations of the World Health Organization”. Regulation [4] established the reference levels, which are $2 \mathrm{kV} / \mathrm{m}$ for electric field strength and $40 \mu \mathrm{T}$ for magnetic flux density. These reference levels refer to rms values of the power frequency field $(50 \mathrm{~Hz})$ in the areas of increased sensitivity. 
The Regulation on Sources of Non-Ionizing Radiation of Special Interest, Types of Sources, Methods and Frequentness of their Testing [5] requires that higher attention is paid to the so-called "sources of special interest". These sources are defined as "sources of electromagnetic radiation that can be harmful to people's health and are determined as stationary and mobile sources whose electromagnetic field in an area of increased sensitivity amounts to at least $10 \%$ of the reference level prescribed for that frequency". For power frequency field, $10 \%$ of the reference levels amounts to $0.2 \mathrm{kV} / \mathrm{m}$ for electric field strength and $4 \mu \mathrm{T}$ for magnetic flux density. Owners of sources of special interest have the obligation of providing field testing once every four years.

\section{DETERMINING THE ZONE OF INFLUENCE}

The zone of influence of an overhead power line depends on many factors. The most influential ones are voltage level $(U)$, maximum permitted load current $\left(I_{\max }\right)$, heights of phase conductors above ground $(h)$, and distances between phase conductors $(a)$. In the case of double-circuit overhead power lines the vectorsequence of the phases also has a significant effect on the width of the zone of influence. To determine the zone of influence, it is important to analyze the distribution of electric field strength $(E)$ and magnetic flux density $(B)$ along the lateral profile (perpendicular to the power line axis), at a height of $1 \mathrm{~m}$ above ground.

An analysis was conducted for $110 \mathrm{kV}, 220 \mathrm{kV}$ and $400 \mathrm{kV}$ overhead power lines in order to determine the maximum width of the zone of influence for each voltage level.

For the purposes of this analysis, the zone of influence is defined as the area in which the values of electric field strength and magnetic flux density amount to at least $10 \%$ of the reference levels, i.e. $0.2 \mathrm{kV} / \mathrm{m}$ and $4 \mu \mathrm{T}$, respectively. The distances from the axis of a power line to the point after which the values of electric field strength and magnetic flux density diminish below $0.2 \mathrm{kV} / \mathrm{m}$ and $4 \mu \mathrm{T}$ are denoted by $l_{E}$ and $l_{B}$, respectively. If the field distribution is symmetrical in relation to the power line axis, the width of the zone of influence is equal to $2 \times l_{E}$ regarding the electric field strength and $2 \times l_{B}$ with regard to the magnetic flux density. Since the zone of influence concerning the electric field strength differs from the one referring to the magnetic flux density, the wider of these two zones is considered to be the relevant zone of influence.

The most common configurations of single- and double-circuit overhead power lines pertaining to the Serbian transmission system are taken into consideration [6]. In regard to the $110 \mathrm{kV}$ voltage level, single-circuit lines with horizontal and triangular phase conductor dispositions are analyzed. Regarding $220 \mathrm{kV}$ and $400 \mathrm{kV}$ voltage levels, single-circuit lines with horizontal dispositions and two different tower designs with different distances between phase conductors are considered. For all the voltage levels, double-circuit lines with approximately vertical phase conductor disposition are taken into consideration as the most common ones [6].
The analysis performed for all three voltage levels has shown that power lines with the horizontal phase conductor disposition have the widest zone of influence. The tower type used for these power lines is shown in Figure 1. Its dimensions for different voltage levels are given in Table 1.

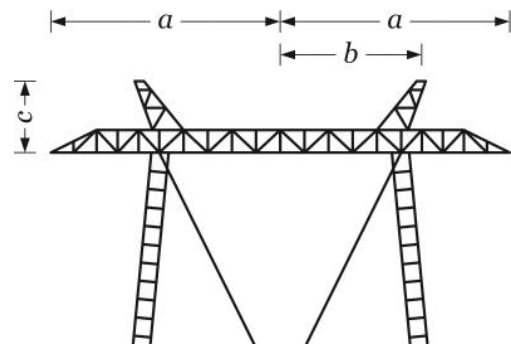

Figure 1. Tower used for $110 \mathrm{kV}, 220 \mathrm{kV}$ and $400 \mathrm{kV}$ singlecircuit lines with horizontal phase conductor disposition

Table 1. Dimensions of towers used for $110 \mathrm{kV}, 220 \mathrm{kV}$ and $400 \mathrm{kV}$ overhead power lines

\begin{tabular}{|c|c|c|c|}
\hline \multirow{2}{*}{$\begin{array}{c}\text { Voltage level } \\
{[\mathrm{kV}]}\end{array}$} & \multicolumn{3}{|c|}{ Dimensions [m] } \\
\cline { 2 - 4 } & $a$ & $b$ & $c$ \\
\hline 110 & 6.7 & 4.5 & 2.5 \\
\hline 220 & 8.5 & 5.2 & 3.5 \\
\hline 400 & 11.8 & 7.8 & 3.4 \\
\hline
\end{tabular}

\section{ELECTRIC FIELD STRENGTH AND MAGNETIC FLUX DENSITY CALCULATIONS}

The calculations are based on a two-dimensional analysis using the method of image charges, which is described in $[7,8]$. Different methods for the calculations of electric field strength and magnetic flux density are presented in [9-15].

The calculations are performed for the geometry presented in Figure 1 and for the data specified in Tables 1 and 2. The data given in Table 2 include types/materials, cross sections $(S)$ and radii $(r)$ of phase conductors and ground wires, lengths of insulator chains (l) which are common for each analyzed voltage level, as well as maximum permitted load currents of the power lines during winter period $\left(I_{\max }\right)$ prescribed by [16]. The current $I_{\max }$ represents the maximum power line load during normal operating conditions.

Table 2. Main technical data referring to analyzed power lines

\begin{tabular}{|c|c|c|c|c|}
\hline $\begin{array}{c}\text { Voltage } \\
\text { level } \\
{[\mathrm{kV}]}\end{array}$ & Phase conductors & Ground wires & $\begin{array}{c}l \\
{[\mathrm{~m}]}\end{array}$ & $\begin{array}{l}I_{\max } \\
{[\mathrm{A}]}\end{array}$ \\
\hline 110 & $\begin{array}{c}\mathrm{ACSR} 240 / 40 \\
r=10.95 \mathrm{~mm}\end{array}$ & $\begin{array}{c}\text { Steel, } \\
S=35 \mathrm{~mm}^{2}, \\
r=3.75 \mathrm{~mm}\end{array}$ & 1.7 & 880 \\
\hline 220 & $\begin{array}{c}\operatorname{ACSR} 490 / 65 \\
r=15.3 \mathrm{~mm}\end{array}$ & $\begin{array}{c}\text { Steel, } \\
S=50 \mathrm{~mm}^{2}, \\
r=4.5 \mathrm{~mm}\end{array}$ & 2.8 & 1370 \\
\hline 400 & $\begin{array}{c}\text { ACSR } \\
2 \times 490 / 65 \\
r=15.3 \mathrm{~mm}\end{array}$ & $\begin{array}{c}\text { Steel, } \\
S=50 \mathrm{~mm}^{2}, \\
r=4.5 \mathrm{~mm}\end{array}$ & 4 & 2740 \\
\hline
\end{tabular}


The calculations are performed for the most typical phase conductor heights, starting with the minimum phase conductor heights permitted in populated areas in Serbia. These minimum heights are prescribed by [17], and amount to $7 \mathrm{~m}, 7.75 \mathrm{~m}$ and $9 \mathrm{~m}$ for $110 \mathrm{kV}$, $220 \mathrm{kV}$ and $400 \mathrm{kV}$ overhead power lines, respectively.

\section{RESULTS AND DISCUSSION}

\subsection{Results for the $110 \mathrm{kV}$ voltage level}

The electric field strength and magnetic flux density distributions along the lateral profile obtained by calculations for the $110 \mathrm{kV}$ power line are presented in Figures 2 and 3, respectively.

The calculations are performed for the phase conductor heights of $7 \mathrm{~m}, 10 \mathrm{~m}, 15 \mathrm{~m}, 20 \mathrm{~m}, 25 \mathrm{~m}$ and $30 \mathrm{~m}$. Since electric field strength and magnetic flux density distributions are symmetrical in respect to the power line axis, only one side of the distribution is presented for each field.

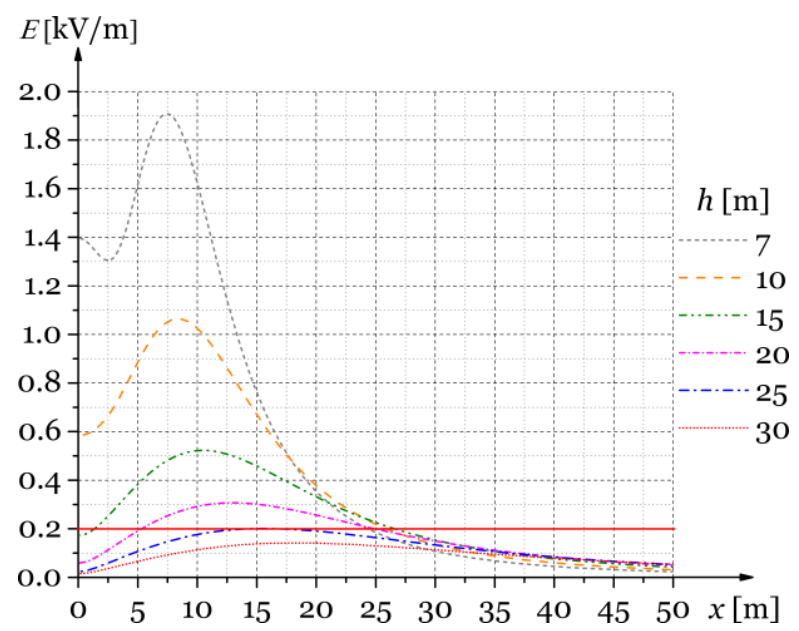

Figure 2. Electric field strength distribution along the lateral profile at the height of $1 \mathrm{~m}$ above ground for $U=110 \mathrm{kV}$,

$a=6.7 \mathrm{~m}, h=7 \mathrm{~m} ; 10 \mathrm{~m} ; 15 \mathrm{~m} ; 20 \mathrm{~m} ; 25 \mathrm{~m} ; 30 \mathrm{~m}$.

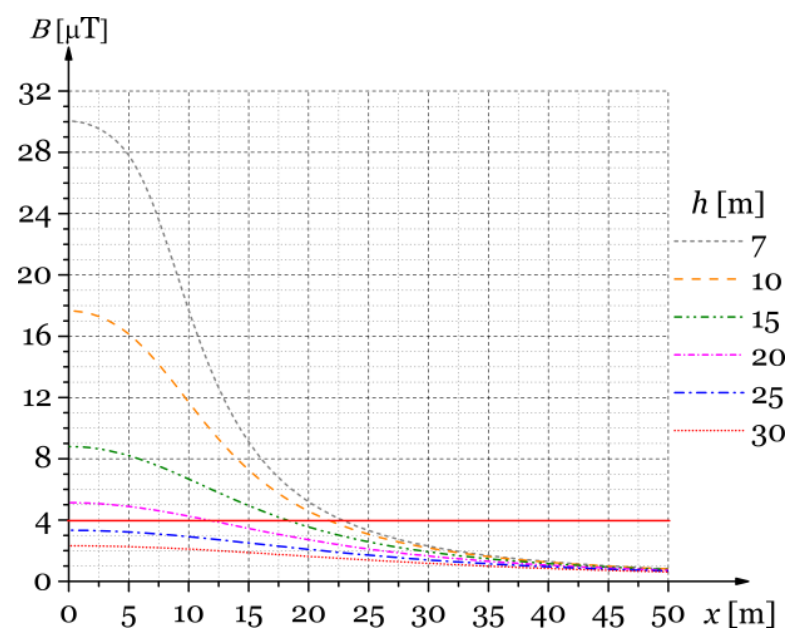

Figure 3. Magnetic flux density distribution along the lateral profile at the height of $1 \mathrm{~m}$ above ground for $I_{\max }=880 \mathrm{~A}$, $a=6.7 \mathrm{~m}, h=7 \mathrm{~m} ; 10 \mathrm{~m} ; 15 \mathrm{~m} ; 20 \mathrm{~m} ; 25 \mathrm{~m} ; 30 \mathrm{~m}$.
As expected, the highest values of electric field strength and magnetic flux density correspond to the case in which phase conductors are at their minimum height. However, the increase of phase conductor heights above ground in some situations can result in the increase of the width of the zone inside which the level of $0.2 \mathrm{kV} / \mathrm{m}$ is exceeded. It is important to note that at greater distances from the line axis the values of electric field strength and magnetic flux density corresponding to different phase conductor heights become very similar and do not depend on the conductor heights.

It can be noticed from Figures 2 and 3 that both $l_{E}$ and $l_{B}$ depend on phase conductor heights. The values of $l_{E}$ and $l_{B}$ for different phase conductor heights are given in Table 3 .

Table 3. Values of $l_{E}$ and $l_{B}$ for different phase conductor heights for the $110 \mathrm{kV}$ voltage level

\begin{tabular}{|c|c|c|}
\hline$h[\mathrm{~m}]$ & $l_{E}[\mathrm{~m}]$ & $l_{B}[\mathrm{~m}]$ \\
\hline 7 & 24 & 22 \\
\hline 10 & 25 & 21 \\
\hline 15 & 26 & 18 \\
\hline 20 & 24 & 11 \\
\hline 25 & 17 & $/$ \\
\hline 30 & $/$ & $/$ \\
\hline
\end{tabular}

Since after certain distance from the power line axis the values of electric field strength do not change significantly with the change of phase conductor heights, the values of $l_{E}$ obtained for the phase conductor heights of $7 \mathrm{~m}, 10 \mathrm{~m}, 15 \mathrm{~m}$ and $20 \mathrm{~m}$ are very similar.

From the data shown in Table 3 it can be observed that for all analyzed phase conductor heights the values of $l_{E}$ are greater than the values of $l_{B}$. The largest value of $l_{E}$ amounts to $26 \mathrm{~m}$ and corresponds to the phase conductor height of $15 \mathrm{~m}$, while the largest value of $l_{B}$ amounts to $22 \mathrm{~m}$ and refers to the phase conductor height of $7 \mathrm{~m}$. Therefore, with regard to $110 \mathrm{kV}$ overhead power lines, the zone of influence width amounts to $2 \times 26 \mathrm{~m}$.

The results of electric field strength and magnetic flux density obtained by calculations for the analyzed $110 \mathrm{kV}$ overhead power line do not exceed the reference levels prescribed by Serbian and international legislation.

\subsection{Results for the $220 \mathrm{kV}$ voltage level}

The electric field strength and magnetic flux density distributions referring to the $220 \mathrm{kV}$ overhead power line are presented in Figures 4 and 5, respectively. The analysis is carried out for the phase conductor heights of $7.75 \mathrm{~m}, 10 \mathrm{~m}, 15 \mathrm{~m}, 20 \mathrm{~m}, 25 \mathrm{~m}$ and $30 \mathrm{~m}$.

The values of $l_{E}$ and $l_{B}$ for different phase conductor heights are given in Table 4 . As in the case of $110 \mathrm{kV}$ power line, the values of $l_{E}$ are again greater than the values of $l_{B}$ for all analyzed phase conductor heights. The largest value of $l_{E}$ amounts to $42 \mathrm{~m}$ and refers to the heights of $20 \mathrm{~m}$ and $25 \mathrm{~m}$. The largest value of $l_{B}$ of $32 \mathrm{~m}$ corresponds to the height of $7.75 \mathrm{~m}$. Hence, the 
M. Grbić et al., Determining the zone of influence of overhead power lines..., RAD Conf. Proc., vol. 3, 2018, 52-57

width of the zone of influence regarding $220 \mathrm{kV}$ overhead power lines amounts to $2 \times 42 \mathrm{~m}$.

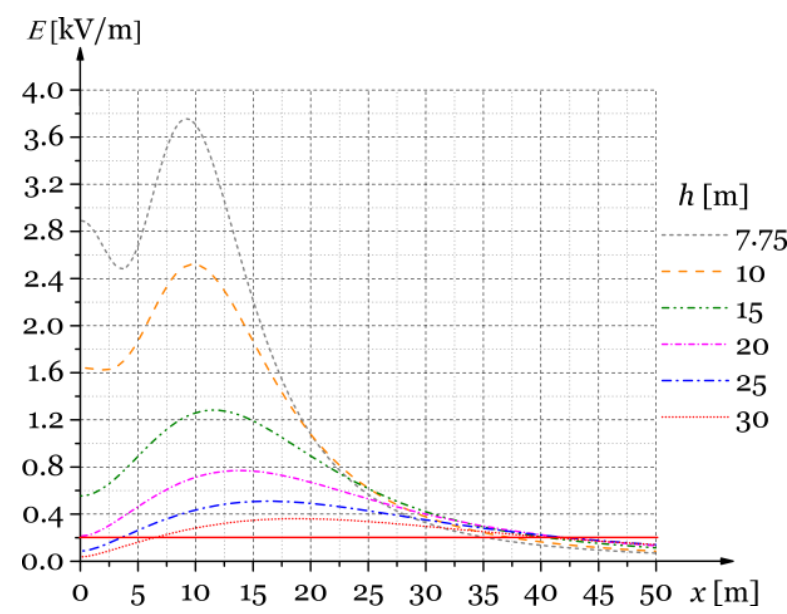

Figure 4. Electric field strength distribution along the lateral profile at the height of $1 \mathrm{~m}$ above ground for $U=220 \mathrm{kV}$, $a=8.5 \mathrm{~m}, h=7.75 \mathrm{~m} ; 10 \mathrm{~m} ; 15 \mathrm{~m} ; 20 \mathrm{~m} ; 25 \mathrm{~m} ; 30 \mathrm{~m}$.

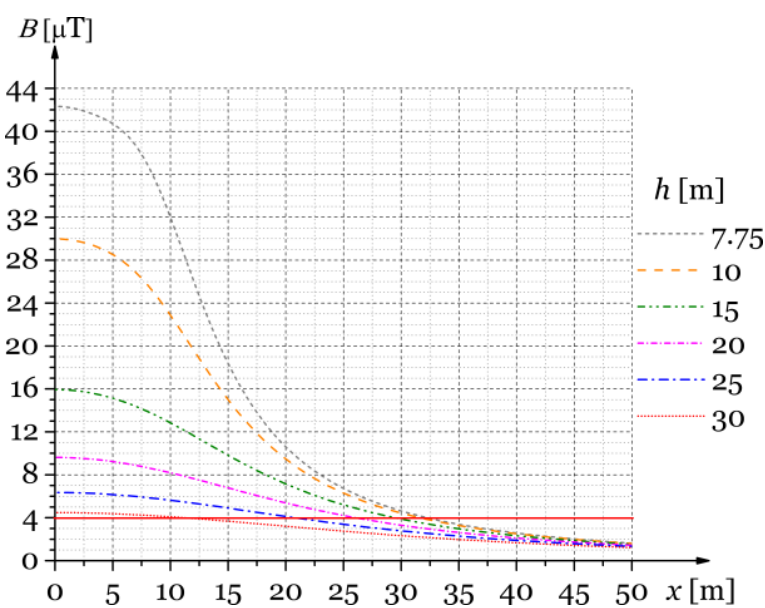

Figure 5. Magnetic flux density distribution along the lateral profile at the height of $1 \mathrm{~m}$ above ground for $I_{\max }=1370 \mathrm{~A}$, $a=8.5 \mathrm{~m}, h=7.75 \mathrm{~m} ; 10 \mathrm{~m} ; 15 \mathrm{~m} ; 20 \mathrm{~m} ; 25 \mathrm{~m} ; 30 \mathrm{~m}$.

Table 4. Values of $l_{E}$ and $l_{B}$ for different phase conductor heights for the $220 \mathrm{kV}$ voltage level

\begin{tabular}{|c|c|c|}
\hline$h[\mathrm{~m}]$ & $l_{E}[\mathrm{~m}]$ & $l_{B}[\mathrm{~m}]$ \\
\hline 7.75 & 35 & 32 \\
\hline 10 & 37 & 31 \\
\hline 15 & 40 & 29 \\
\hline 20 & 42 & 26 \\
\hline 25 & 42 & 20 \\
\hline 30 & 41 & 11 \\
\hline
\end{tabular}

The results of electric field strength obtained by calculations for the analyzed $220 \mathrm{kV}$ overhead power line exceed the reference level of $2 \mathrm{kV} / \mathrm{m}$ in the cases when the phase conductor heights are equal to $7.75 \mathrm{~m}$ and $10 \mathrm{~m}$, but they do not exceed the reference level of $5 \mathrm{kV} / \mathrm{m}$.

The results of magnetic flux density exceed the reference level of $40 \mu \mathrm{T}$ in the case when the phase conductor heights are equal to $7.75 \mathrm{~m}$, but they do not exceed the reference level of $100 \mu \mathrm{T}$.

\subsection{Results for the $400 \mathrm{kV}$ voltage level}

For the $400 \mathrm{kV}$ voltage level, the analysis is conducted for the phase conductor heights of $9 \mathrm{~m}$, $15 \mathrm{~m}, 20 \mathrm{~m}, 25 \mathrm{~m}$ and $30 \mathrm{~m}$. The calculation results are presented in Figures 6 and 7.

Table 5 shows the values of $l_{E}$ and $l_{B}$ for the analyzed phase conductor heights.

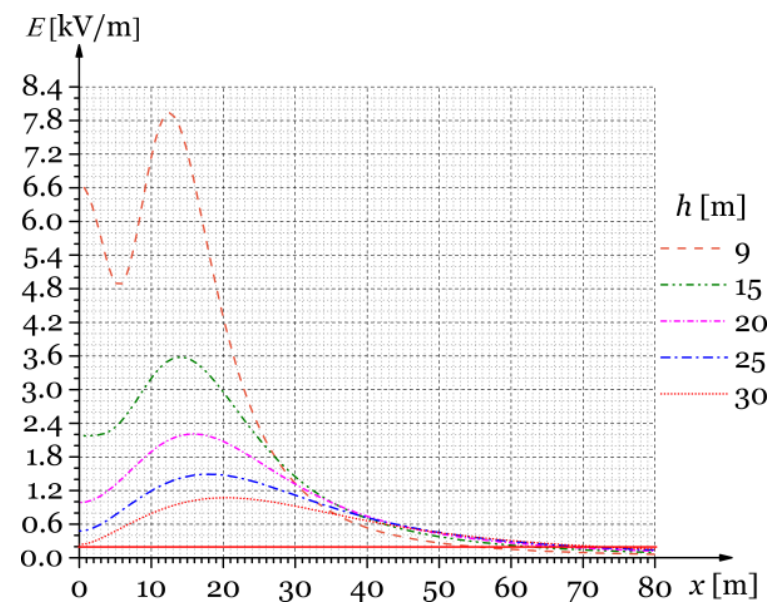

Figure 6. Electric field strength distribution along the lateral profile at the height of $1 \mathrm{~m}$ above ground for $U=400 \mathrm{kV}$, $a=11.8 \mathrm{~m}, h=9 \mathrm{~m} ; 15 \mathrm{~m} ; 20 \mathrm{~m} ; 25 \mathrm{~m} ; 30 \mathrm{~m}$.

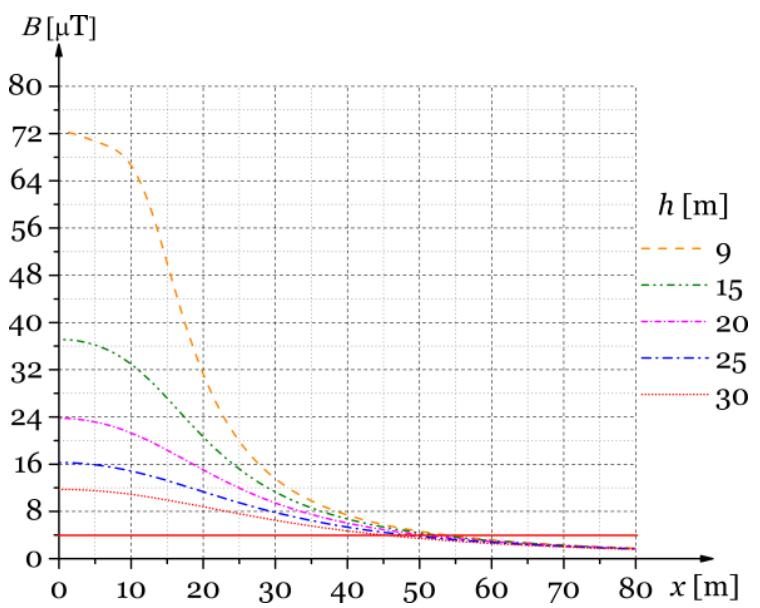

Figure 7. Magnetic flux density distribution along the lateral profile at the height of $1 \mathrm{~m}$ above ground for $I_{\max }=2740 \mathrm{~A}$, $a=11.8 \mathrm{~m}, h=9 \mathrm{~m} ; 15 \mathrm{~m} ; 20 \mathrm{~m} ; 25 \mathrm{~m} ; 30 \mathrm{~m}$

It can be observed that the largest value of $l_{E}$ amounts to $72 \mathrm{~m}$ and refers to the height of $30 \mathrm{~m}$, while the largest value of $l_{B}$ amounts to $53 \mathrm{~m}$ and corresponds to the height of $9 \mathrm{~m}$. Thus, the zone of influence width for $400 \mathrm{kV}$ overhead power lines amounts to $2 \times 72 \mathrm{~m}$. As in the two previous cases, the values of $l_{E}$ are greater than the values of $l_{B}$ for all analyzed phase conductor heights. 
M. Grbić et al., Determining the zone of influence of overhead power lines..., RAD Conf. Proc., vol. 3, 2018, 52-57

Table 5. Values of $l_{E}$ and $l_{B}$ for different phase conductor heights for the $400 \mathrm{kV}$ voltage level

\begin{tabular}{|c|c|c|}
\hline$h[\mathrm{~m}]$ & $l_{E}[\mathrm{~m}]$ & $l_{B}[\mathrm{~m}]$ \\
\hline 9 & 54 & 53 \\
\hline 15 & 62 & 52 \\
\hline 20 & 66 & 50 \\
\hline 25 & 70 & 48 \\
\hline 30 & 72 & 45 \\
\hline
\end{tabular}

The results of electric field strength obtained for the analyzed $400 \mathrm{kV}$ overhead power line exceed the reference level of $2 \mathrm{kV} / \mathrm{m}$ in the cases when the phase conductor heights are equal to $9 \mathrm{~m}, 15 \mathrm{~m}$ and $20 \mathrm{~m}$. The reference level of $5 \mathrm{kV} / \mathrm{m}$ is exceeded in the case when the phase conductor heights are equal to $9 \mathrm{~m}$.

The results of magnetic flux density exceed the reference level of $40 \mu \mathrm{T}$ in the case when the phase conductor heights are equal to $9 \mathrm{~m}$, but they do not exceed the reference level of $100 \mu \mathrm{T}$.

\section{CONCLUSION}

The performed analysis shows that the zone of influence widths amount to $2 \times 26 \mathrm{~m}, 2 \times 42 \mathrm{~m}$ and $2 \times 72 \mathrm{~m}$ for $110 \mathrm{kV}, 220 \mathrm{kV}$ and $400 \mathrm{kV}$ overhead power lines, respectively. These zones refer to the analyzed power lines with specified tower geometries and input data. Outside of these zones, the levels of power frequency electric field strength and magnetic flux density are lower than $10 \%$ of the reference levels prescribed in Serbia, regardless of phase conductor heights. Electric and magnetic field measurements should be carried out only in areas of increased sensitivity located within the aforementioned zones of influence. In planning the construction of new power lines near residential areas and residential buildings near existing power lines, the zones of influence presented in this paper should be taken into consideration.

\section{REFERENCES}

1. The Council of the European Union. (Jul. 12, 1999). (1999/519/EC) Council recommendation of 12 July 1999 on the limitation of exposure of the general public to electromagnetic fields ( $\mathrm{OHz}$ to $30 \mathrm{O} \mathrm{GHz}$ ).

Retrieved from: https://publications.europa.eu/en/publ ication-detail/-/publication/9509bo4f-1dfo-4221-bfa2c7af77975556/language-en;

Retrieved on: Jul. 2, 2018

2. P. Vecchia et al., "ICNIRP Guidelines for limiting exposure to time-varying electric and magnetic fields (1 Hz - $100 \mathrm{kHz})$," Health Phys., vol. 99, no. 6, pp. $818-836$, Dec. 2010.

DOI: 10.1097/HP.obo13e3181fo6c86 PMid: 21068601

3. Влада Републике Србије. (15.5.2009). Сл. Гласник 36/2009 Закон о заштити од нејонизујућих зрачења. (Government of the Republic of Serbia. (May 15, 2009). Official Gazzete 36/2009 Law on protection from non ionizing radiation.) Retrieved from: https://www.paragraf.rs/propisi/zakon o zastiti od nejonizujucih zracenja.html; Retrieved on: Jul. 3, 2018
4. Министарство животне средине и просторног планирања. (15.5.2009). Правилник о границама излагања нејонизујућим зрачењима. (Ministry of environmental protection and spatial planning. (May 15, 2009) Rulebook on limitations of exposure to non ionizing radiation.)

Retrieved from: http://www.sepa.gov.rs/download/stra no/pravilnik5.pdf;

Retrieved on: Jul. 3, 2018

5. Министарство животне средине и просторног планирања. (16.12.2009). Правилник о изворима нејонизујућих зрачења од посебног интереса, врстама извора, начину и периоду њиховог испитивања. (Ministry of environmental protection and spatial planning. (Dec. 16, 2009). Rulebook on sources of non ionizing radiation of special interest, types of sources, manner and period of their examination.)

Retrieved from: http://www.sepa.gov.rs/download/stra no/pravilnik1.pdf;

Retrieved on: Jul. 3, 2018

6. Мере за ограничење електричног и магнетског поља, студија бр. 3414017 , Електротехнички институт „Никола Тесла”, Београд, Србија, 2014. (Techniques for limiting the levels of electric and magnetic field, study no. 3414017, Nikola Tesla Electrical Engineering Institute, Belgrade, Serbia, 2014.)

7. Electric and magnetic field levels generated by $A C$ power systems - Measurement procedures with regard to public exposure, EN 62110:2009, Aug. 38, 2009.

8. "Electric and magnetic fields," in EPRI AC transmission line reference book $-200 \mathrm{kV}$ and above, 3rd ed., Palo Alto (CA), USA: EPRI, 2005, ch. 7, pp. 7.1-7.118.

Retrieved from: https://www.scribd.com/document/332 960172/EPRI-AC-Transmission-Line-Reference-Book200-kV-and-above-3rd-Ed-2005-pdf;

Retrieved on: Jul. 2, 2018

9. Evaluation techniques and working procedures for compliance with exposure limits of network operator personnel to power-frequency electromagnetic fields, K.90 (07/2018), Jul. 14, 2018.

10. G. Lucca, "Magnetic field produced by power lines with complex geometry," Eur. T. Electr. Power., vol. 21, no. 1 , pp. $52-58$, Jan. 2011.

DOI: $10.1002 /$ etep.411

11. A. Z. El Dein, "Calculation of the electric field around the tower of the overhead transmission lines," IEEE T. Power. Deliver., vol. 29, no. 2, pp. 899 - 907, Apr. 2014.

DOI: 10.1109/TPWRD.2013.2273500

12. A. Z. El Dein, "Parameters affecting the charge distribution along overhead transmission lines' conductors and their resulting electric field," Electric Power Syst. Res., vol. 108, pp. 198 - 210, Mar. 2014. DOI: 10.1016/j.epsr.2013.11.011

13. J. C. Salari, A. Mpalantinos, J. I. Silva, "Comparative analysis of 2- and 3-D methods for computing electric and magnetic fields generated by overhead transmission lines," IEEE T. Power. Deliver., vol. 24, no. 1, pp. 338 344, Jan. 2009. DOI: 10.1109/TPWRD.2008.923409

14. T. Modrić, S. Vujević, D. Lovrić, " $3 \mathrm{D}$ computation of the power lines magnetic field,” Prog. Electromagn. Res., vol. 41, pp. 1- 9, 2015 . DOI: 10.2528/PIERM14122301

15. T. Modrić, S. Vujević, "Computation of the electric field in the vicinity of overhead power line towers," Electric Power Syst. Res., vol. 135, pp. 68 - 76, Jun. 2016. DOI: 10.1016/j.epsr.2016.03.004

16. Дозвољене струје фазних проводника на далеководима, Техничко упутство ТУ-ДВ-о4, верзија 2, ЈП „Електромрежа Србије”, Београд, Србија, 2011. (Allowed current values of phase conductors in 
M. Grbić et al., Determining the zone of influence of overhead power lines..., RAD Conf. Proc., vol. 3, 2018, 52-57

transmission lines, Technical Manual ТУ-ДВ-04, version 2, SOE Elektromreža Srbije, Belgrade, Serbia, 2011.)

17. Влада Савезне Републике Југославија. (1992) Правилник о техничким нормативима за изградњу надземних електроенергетских водова називног напона од $1 \mathrm{kV}$ до $40 \mathrm{kVV}$. (Government of the Federal Republic of Yugoslavia. (1992). Rulebook on technical norms for building of overground electric transmission lines of the nominal voltage of $1 \mathrm{kV}$ to $400 \mathrm{kV}$.)

Retrieved from: http://www.vladars.net/sr-SP-

Cyrl/Vlada/Ministarstva/mper/std/Documents/3.Pravil nik\%200\%20\%20teh.\%20norm.za\%20izgrd.\%2onadze mnih\%20el.\%20vodova\%20naz.\%20napons\%201kv\%20 do\%20400kv\%20SL.L.\%20SFRJ\%2065-88.pdf Retrieved on: Jul. 3, 2018 